\title{
The Effect of Organizational Culture, Transformational Leadership, Vertical Communication Toward Lecturers' Organizational Commitment at Serambi Mekah University of Banda Aceh
}

\author{
Sariakin* Biner Ambarita Abdul Muin Sibuea \\ State University of Medan, Jl. Willem Iskandar Psr. V Medan, Indonesia
}

\begin{abstract}
This study aims to find out and examine the influence of organizational culture, transformational leadership, and vertical communication on the lectures' organizational commitment in Teacher Training and Education Faculty, Mekah University Banda Aceh that consist of to 110 lecturers. The samples are 60 lecturers. The data are collected using a questionnaire filled out by respondents, and then the data are processed using regression analysis. The results show that: independent variable partially has a significant effect on the dependent variable, it is known that the organizational culture variable is $6.903>\mathrm{t}$ table is 2,000. Ho is rejected and $\mathrm{H} 1$ is accepted, so it can be stated partially that organizational culture has a significant effect on organizational commitment; whereas for transformational leadership variables the value of tcount is $5.406>\mathrm{t}$ table is 2,000 . Ho is rejected, so it can be stated partially that transformational leadership has a significant effect on organizational commitment; and vertical communication variable tcount is $2.668>\mathrm{t}$ table is 2,000 . Ho is rejected, so it can be stated partially that vertical communication has a significant effect on organizational commitment. Simultaneous contribution of variable organizational culture, transformational leadership, and vertical communication to organizational commitment is obtained by the value of Fcount $=81.403$, and Ftable $=2.77$. Because Fcount $>$ Ftable means that Ho is rejected and $\mathrm{Ha}$ is accepted, so it can be concluded that there is a significant effect simultaneously between $\mathrm{X} 1$, X2, and $\mathrm{X} 3$ towards $\mathrm{Y}$.
\end{abstract}

Keywords: Organizational Culture, Transformational Leadership, Vertical Communication, Organizational Commitment

DOI: $10.7176 / \mathrm{JEP} / 10-12-11$

Publication date: April $30^{\text {th }} 2019$

\section{INTRODUCTION}

Qualified lecturers have a high commitment to the university so that it can develop various plans more steadily and sustainably. However, it seems that most universities in Indonesia have not seen the importance of the role of lecturers' commitment to improve the quality and development of universities. On the other hand, mostly universities are unable to take decisive action against lecturers who are not too much involved in activities on campus, including in education and teaching activities. In fact, it is something important to take seriously.

High organizational commitment is important so that lecturers are passionate in building scientific insights and competencies in students. However, the problem that arises is how far the organization's commitment to education level, gender, age, years of service, and employment status is at Serambi Mekah University, Banda Aceh. As an organization, university is living organisms that consist of academic activities that interact with each other. Traditionally, university is defined as the self governing corporation of scholars. It means that it is a community of self-regulating educated people. The university is one of the most dominant social organizations in the world because it has an important role in preparing someone to occupy positions and join certain professions, transmit culture to the next generation, give criticism to the community, and produce and apply science.

Based on the results of interview with the dean of teacher training and education faculty Serambi Mekah University, Abu Bakar, on April 22, 2018, the quality of the achievement of the objectives of each study program is low, which leads to the low quality of education. Factors causing low quality of education, especially in Banda Aceh, are management problems that are closely related to improve the quality of education. In general, the education management in Banda Aceh, especially at Serambi Mekah University, has not been able to explore the full potential to work together in supporting the process of optimal learning activities. To highlight the quality of higher education in Aceh Province, the Coordinator of Kopertis Region XIII calls on conducting research with competing sources of grant funds. He appeals an effort to improve education to conduct research that focuses on mapping education staff.

Based on the results of preliminary observations carried out, there are still indications of the ineffectiveness of the existing work in higher education institutions in Aceh, especially in at Serambi Mekah University such as: the number of lecturers for several work units is very small and this is not in accordance with the volume of activities in the work unit that causes overloading of lecturers' conditions and the expected targets cannot be achieved, the condition of employees who are stressed because they have to complete deadline work, work that 
emphasizes the final results so that group dynamics through communication and coordination are very few that cause interpersonal relationships to be low, lack of rest time because it is used to complete work, the conflict among of the lecturers in the organization is due to each of them pursues the target of completing the work, lack of trust between lecturers in the organization.

Colquitt, Lepine, and Wesson (2009: 8) it is found that empirically several variables that influence organizational commitment and job performance, they are: (1) job satisfaction; (2) stress; (3) motivation; (4) trust, justice and ethics; and (5) learning and decision making. While the variables that go through the five variables above affect organizational commitment are (1) organizational culture; (2) organizational structure; (3) leadership style and behavior; (4) leadership power and influence; (5) process; (6) characteristics; (7) cultural values and personality; and (8) ability.

Newstrom's organizational behavior system (2000: 26), motivational variables directly influence (1) performance, (2) job satisfaction, and (3) personal growth and development. While variables (1) leadership, (2) communication, and ( 3 ) group dynamics, through variables (1) quality of work and (2) motivation, affecting variables (1) performance, (2) job satisfaction, and (3) personal growth and development, as output variables. While organizational culture variables directly influence variables (1) leadership, (2) communication, and (3) group dynamics; and then through variables (1) quality of work atmosphere and (2) motivation, influencing variable (1) performance, (2) job satisfaction, and (3) personal growth and development as output variables. While philosophy, values, vision, mission, organizational goals, informal organizations, formal organizations, and social environments directly affect organizational culture.

Based on the description above, this study is conducted on the influence of organizational culture, transformational leadership, and vertical communication on organizational commitment in Serambi Mekah University, Banda Aceh. Therefore, it is necessary to identify the factors that influence the organizational commitment at the university, in order to find a model that effectively enhances the organizational commitment.

\section{LITERATURE REVIEW}

\subsection{Organizational Commitment}

Organizational commitment is a condition in which a person sits with a particular organization and its goals and desires to maintain membership in the organization. It is classified as a person's attitude, which means at the extent to which someone relates himself to a particular organization and its goals and hopes to maintain membership in the organization. Robbin and Judge (2007) state that organizational commitment is a situation where an employee accord with the organizational goal to maintain membership in the organization.

Mathis and Jackson (2006) organizational commitment is the level up to where employees are confident and accept organizational goals, and willing to live with the organization. According to Kreitner and Kinicki (2007) that organizational commitment is a reflection where an employee recognizes the organization and is bound to goals this is an important work attitude because people have a commitment that is expected to be able to show its availability to work harder to achieve organizational goals and have a greater desire to continue working in a company. It is a situation where an employee sits with a certain organization and its objectives and intends to maintain its membership in the organization.

Sopiah (2008) states that organizational commitment is a psychological bond on employees that is characterized by the existence of trust and strong acceptance of organizational goals and values, the willingness to strive for achieving organizational interests and the desire to maintain position as members of the organization. (2006) it is a reflection of employee loyalty and an ongoing process in which members of the organization express their concern for the organization and the belief in accepting organizational values and goals.

Based on the description related to the explanation of various experts, organizational commitment is continuous involvement and cohesiveness and control, being positive and decisive in behaving, having accountability and being consistent in carrying out their decisions and always proactive towards their duties and work for leaders of the organization. The indicators are: Feelings proud to have been part of the organization, strong desire to remain as a member of the organization, obedience to organizational policy even without a boss, willing to sacrifice personal goals or interests to achieve organizational goals, desire to strive and enthusiasm in work, trust in strong acceptance of values and goals organization.

\subsection{Vertical Communication}

Communication in Organizations is a process of delivering information, ideas, among members of the organization reciprocally in order to achieve the stated goals. According to Eugene (1995: 224), communication is a process in organizing to maintain that management and employees remain aware of various relevant matters. Haryani (2001: 5) communication is a process by which someone (communicator) sends stimuli (usually with verbal symbols) to change behavior from other people (communicants). The principle of two-way communication and reciprocity (paradigmatic) is the process of delivering a message from a person or group (communicator) to tell orchange attitudes, opinions, behavior to individuals or groups (communicants), both directly and indirectly, through mass 
media as a tool to achieve the target in the two-way communication process.

Muhammad (2007: 5) states that communication is the exchange of verbal and non verbal messages between the sender and the recipient of the message to change behavior. According to Robbins (2007), there are 4 functions of communication, as follows: 1) Control behavior of members in several ways, so that instructions are adhered to by subordinates. 2) Motivation, fostering motivation by explaining to employees what to do, how well they work, and what must be done to improve performance. 3) Means of expressing emotions (satisfaction, frustration, etc.) 4) providing information that makes decision making easier.

Based on the explanation above, the vertical communication indicators in this study are: Positive attitude that refers to at least two aspects of interpersonal communication. It builds up if people have a positive attitude towards themselves. Positive feelings for communication situations are generally very important for effective interaction, equality with indicators. Keep respecting themselves and others, so that satisfying interactions are achieved.

\subsection{Transformational leadership}

Transformational leadership is the last approach that is warmly discussed during the last two decades. Yukl (2010) describes that leaders will change and motivate followers with a tendency to do ways such as: (1) make followers more aware of the importance of task results from work done, (2) educating participants to prioritize the interests of the team or organization rather than individual interests, (3) activating higher followers' needs. Transformational leaderships increase motivation and performance of followers compared to transactional leadership, which emphasizes reciprocal exchange processes with an emphasis on individual interests. Therefore, transformational leaderships have behaviors including: having an ideal influence, paying attention to individual considerations, providing inspirational motivation, and making intellectual stimulation

Antonakis et al. (2003) define transformational leadership as a behavior that is proactive, increases attention to shared interests to followers, and helps followers achieve goals at the highest level. In transformational leadership, leaders change the beliefs, values, and behavior of followers so that they are consistent with the vision of the organization. Khuntia and Suar (2004) assert that leaders who apply transformational leadership have an influence on followers by involving followers participating in goal setting, problem solving, decision making, and providing feedback through training, direction, consultation, guidance, and monitoring of tasks that given.

Transformational leaders make followers become more aware of the interests and values of work and persuade followers not to prioritize self-interest for the organization. After paying attention to the description and explanation of transformational leadership, the characters that can be used as indicators in transformational leadership are as follows: leadership function; have integrity ( the leader has the desire to build mutual trust by setting an example and showing high consistency between words and deeds); have self-confidence (followers see their leaders do not hesitate in acting, leaders need to show their confidence to convince their followers about the truth of the goals and decisions); being a good role model (as a leader must be characterized so that it can be used as a role model by the leader)

\subsection{Organizational culture}

Organizational culture is a norm, values, assumptions, beliefs, philosophy, organizational habits, and so on (the contents of organizational culture) that are developed for a long time by founders, leaders, and members of organizations that are socialized and taught to new members and applied in activities organization so it influences the mindset, attitudes, and behavior of organizational members in producing products, serving consumers, and achieving organizational goals. Robbin and Judge (2007) also explain that organizational culture concerns how members see the organization, not whether members of the organization like it or not, because members absorb organizational culture based on what they see or hear in the organization.

Members of the organization tend to perceive the same about the culture in the organization even though they come from different backgrounds or work at different levels of expertise within the organization. According to Sutrisno (2009), organizational culture is a pattern of shared assumptions learned by a group in solving problems through external adaptation and internal integration. Internal integration includes vision, mission, technology, and organizational structure. In this case, the lecturers develop a collective identity and know how to work together effectively. This is a culture that guides daily work relationships and determines how employees are encouraged to work in a structured way in terms of delivering information from subordinates to superiors and vice versa

Based on the explanation of attitude theory and organizational culture, a basic understanding of organizational culture can be drawn as a positive infection or negative affection towards organizational culture (in the form of shared values, beliefs and habits in organizations that interact with formal structures to produce norms). Organizational culture variables are used to be carried out in this study then several indicators, namely: establishing cooperation, process oriented, employee oriented, open system, tolerance to conflict, and communication patterns.

\section{RESEARCH METHODS}

This research is conducted in the University of Serambi Mekkah in Banda Aceh at the Teacher Training and 
Education Faculty. The population in this study is the permanent lecturer which amounts to 110 lecturers, while a sample consisted of 60 lecturers.

\subsection{Data analysis technique}

Analysis of the data used in this study includes descriptive analysis, analysis requirements test, and hypothesis testing. In accordance with the research instruments used to capture data are questionnaires of each variable. To identify the tendency of each research variable the average ideal score and standard deviation are used and ideal for each variable by referring to the normal curve.

\subsection{Test the Research Hypothesis}

This research is carried out to examine events that have occurred and then trace back to find out the factors that cause the occurrence of an event. To test the hypothesis used regression analysis with the help of SPSS for Windows version 25.0 computer program. In hypothesis testing, a significance level of $\alpha$ of 0.05 is used.

\section{RESEARCH RESULTS}

Based on the hypothesis tested, data analysis requirements need to be carried out. Requirements for the data needed to test hypotheses are data that are normally distributed and linear so that the results of research can be accounted for if the sample is taken randomly. Research problems are formulated. Computational regression coefficients and their summaries are summarized. Multiple linear regression equations are shown in the following figure.

Table 1 Regression Coefficients

\begin{tabular}{|c|c|c|c|c|c|c|}
\hline \multicolumn{7}{|c|}{ Coefficients $^{a}$} \\
\hline \multirow{2}{*}{\multicolumn{2}{|c|}{ Model }} & \multicolumn{2}{|c|}{ Unstandardized Coefficients } & \multirow{2}{*}{$\frac{\text { Standardized Coefficient }}{\text { Beta }}$} & \multirow[b]{2}{*}{$\mathrm{T}$} & \multirow[b]{2}{*}{ Sig. } \\
\hline & & $\mathrm{B}$ & Std. Error & & & \\
\hline \multirow[t]{4}{*}{1} & (Constant) & $-34,664$ & 9,469 & & $-3,661$ & 0,001 \\
\hline & $\mathrm{X} 1$ & 0,549 & 0,080 & 0,48 & 6,903 & 0,000 \\
\hline & $\mathrm{X} 2$ & 0,476 & 0,088 & 0,412 & 5,406 & 0,000 \\
\hline & $\mathrm{X} 3$ & 0,217 & 0,081 & 0,18 & 2,668 & 0,010 \\
\hline
\end{tabular}

Explanations:

$\mathrm{X}_{1}=$ Organizational Culture

$\mathrm{X}_{2}=$ Transformational Leadership

$\mathrm{X}_{3}=$ Vertical Communication

$\mathrm{Y}=$ Organizational Commitment

The output of the regression analysis above, the constant value (a) is obtained at $-34,664$, the regression slope value (a1) is obtained by 0.549 with the value of nig. 0,000 , the regression slope value (a2) is 0.476 with the value of nig. 0,000 , and the regression slope value (a3) is obtained 0.217 with the value of nig. 0.010 . Thus the regression equation can be written as follows:

$\mathrm{Y}=\mathrm{a}+\mathrm{a} 1 \mathrm{X} 1+\mathrm{a} 2 \mathrm{X} 2+\mathrm{a} 3 \mathrm{X} 3$

$\mathrm{Y}=-34,664+0,549 \mathrm{X} 1+0,476 \mathrm{X} 2+0,217 \mathrm{X} 3$

The results of testing the hypothesis as presented in Table 1, to find out whether in the independent variable regression model (free) partially has a significant effect on the dependent variable (bound), it can be seen by comparing with the nig values found in table 1 above or $t$ table by making a decision: If ttable $>$ tcount then Ho is accepted, if $t$ table $<\mathrm{t}$ count then Ho is rejected. Based on Table 1 above, it can be seen that the tcount of the organizational culture variable is $6.903>\mathrm{t}$ table, namely 2,000 . Ho is rejected and $\mathrm{H} 1$ is accepted, it can be stated partially that organizational culture has a significant effect on organizational commitment.

Whereas for transformational leadership variables, the decision making method is as follows: If $\mathrm{t}$ table $>\mathrm{t}$ count then Ho is accepted, if $t$ table $<\mathrm{t}$ count then Ho is rejected. Based on Table 1 above, it can be seen that the $t-$ count of transformational leadership variables is 5.406>t table, namely 2,000. Ho is rejected, so it can be stated partially that transformational leadership has a significant effect on organizational commitment.

Furthermore, for vertical communication variables, the way of decision making is as follows: If $\mathrm{t}$ table $>\mathrm{t}$ count then Ho is accepted, if $t$ table $<t$ count then Ho is rejected. Based on Table 1 above, it can be seen that the $t-$ count of the vertical communication variable is $2.668>\mathrm{t}$, which is 2,000 . Ho is rejected, so it can be stated partially that vertical communication has a significant effect on organizational commitment.

The regression equation needs to be tested significantly by looking at the $\mathrm{F}$ value and the sig value. Simultaneous hypothesis testing is needed to find out whether the regression model is correct or incorrect. Hypothesis testing uses the number F, which is obtained from the following ANOVAs table: 
Table 2 F-Test Results

\begin{tabular}{|c|c|c|c|c|c|c|}
\hline \multicolumn{7}{|c|}{ ANOVA $^{\mathrm{a}}$} \\
\hline \multicolumn{2}{|c|}{ Model } & $\begin{array}{l}\text { Sum of } \\
\text { Squares }\end{array}$ & Df & $\begin{array}{l}\text { Mean } \\
\text { Square }\end{array}$ & $\mathrm{F}$ & Sig. \\
\hline \multirow[t]{3}{*}{1} & Regression & 7634,233 & 3 & 2544,744 & 81,403 &, $000^{\mathrm{b}}$ \\
\hline & Residual & 1750,617 & 56 & 31,261 & & \\
\hline & Total & 9384,850 & 59 & & & \\
\hline
\end{tabular}

Hypothesis testing is done by comparing the magnitude of the F number of research with $\mathrm{F}$ table, with the following criteria:

If $\mathrm{F}$ count $>\mathrm{F}$ table, then Ho is rejected and $\mathrm{Ha}$ is accepted If $\mathrm{F}$ count $<\mathrm{F}$ table, then $\mathrm{Ho}$ is accepted and $\mathrm{Ha}$ is rejected

Based on table 2 above, the research obtained from the calculation results is 81.403 , while the number $\mathrm{F}$ table is calculated with provisions, namely the significance level of $95 \%$ and alpha $5 \%$ and degrees of freedom with the provisions $\mathrm{n}-3-1=56$ this is obtained by lifting $\mathrm{F}$ table $=2.77$. Thus the value of Fcount $=81.403$, and Ftable $=$ 2.77 is obtained. Because Fcount $>$ Ftable means that Ho is rejected and Ha is accepted, so it can be concluded that there is a significant effect simultaneously between $\mathrm{X} 1, \mathrm{X} 2$, and $\mathrm{X} 3$ towards $\mathrm{Y}$.

Determinants are used to find out how much the independent variable is able to explain the influence of independent variables as seen in the following table.

Table 3 F-Test Results

\begin{tabular}{|l|c|r|r|r|}
\hline \multicolumn{5}{|c|}{ Model Summary } \\
\hline Model & R & R Square & Adjusted R Square & Std. Error of the Estimate \\
\hline 1 &, $902^{\mathrm{a}}$ & 0,813 & 0,803 & 5,591 \\
\hline \multicolumn{2}{|c|}{ a. Predictors: (Constant), X3, X1, X2 } \\
\hline
\end{tabular}

From the table above, it can be seen the number of $\mathrm{R} 2$ is 0.813 . It means the variables $\mathrm{X} 1, \mathrm{X} 2$, and $\mathrm{X} 3$, explain the effect on variable $\mathrm{Y}$ of $81.3 \%(\mathrm{R} 2 \times 100 \% ; 0.813 \times 100 \%=81.3 \%)$ while the remaining $8.7 \%(100 \%-\mathrm{R} 2)$ is explained by other variables outside the research model.

\section{DISCUSSION}

To find out whether in the independent variable regression model partially has a significant effect on the dependent variable, it can be seen by comparing with the nig value by making a decision: If $\mathrm{t}$ table $>\mathrm{t}$ count then Ho is accepted, if $\mathrm{t}$ table $<\mathrm{t}$ count then Ho rejected. Based on Table 1 above, it can be seen that the $\mathrm{t}$ count of the organizational culture variable is $6.903>\mathrm{t}$ table 2,000 . Ho is rejected and $\mathrm{H} 1$ is accepted, it can be stated partially that organizational culture has a significant effect on organizational commitment.

A strong culture must be balanced with the ability to adapt to the outside environment. An organization is an open system that can influence, but can also be influenced by the environment which is a dynamic system. To be successful in an ever-changing environment, organizations must be responsive to the possibilities that are likely to occur, be able to read important trends, and be able to make adjustments quickly. At present, there is a tendency towards globalization, the business world is experiencing increasingly strong competition and the source of organizational strength will be more focused on human resources and information technology. The culture of the Serambi Mekah University organization in Banda Aceh is built by collaborative, process-oriented, employeeoriented, open systems, tolerance to conflict, and communication patterns. It will be able to increase the commitment of the lecturers in Banda Aceh. The findings of this study support the theory proposed by Baron and Greenberg (2000: 173) which is used as the basis for submitting theoretical models of research variables,: organizational culture influences commitment.

Whereas for transformational leadership variables, the decision making method is as follows: If $\mathrm{t}$ table $>\mathrm{t}$ count then Ho is accepted, if $t$ table $<\mathrm{t}$ count then Ho is rejected. Based on Table 1 above, it can be seen that the $t-$ count of transformational leadership variables is 5.406>t table, namely 2,000. Ho is rejected, so it can be stated partially that transformational leadership has a significant effect on organizational commitment. Leadership plays a dominant, crucial, and critical role in the overall effort to increase the commitment of lecturers, both at the individual level, at the group level, and at the organizational level. The lecturer in Serambi Mekah University has a good ability to mobilize, direct, coordinate, optimize the resources of the school Hamzah (2008: 69) explains that there are several traits that can be observed from someone who has good transformational leadership, among others: (1) performance depends on the effort and ability it has compared to the organizational commitment of lecturers through groups; (2) have the ability to complete difficult tasks; and (3) there is often concrete feedback about how he should carry out his duties optimally, effectively, and efficiently.

Transformational leadershi provides a perspective to enlighten its ideas. Transformational in its implications 
will generate new ideas and different ways of bringing challenges together as entangling problems. Transformational leadership of lecturers in Serambi Mekah University is expected to have honesty in carrying out its leadership functions; leaders have the desire to build mutual trust by setting an example and showing high consistency between words and deeds. The leaders must be characterized so that they can be used as role models by those who are led. They can increase the lecturers' organizational commitment.

Furthermore, for vertical communication variables, the way of decision making is as follows: If $t$ table $>t$ count then Ho is accepted, if $t$ table $<\mathrm{t}$ count then Ho is rejected. Based on Table 1 above, it can be seen that the $t-$ count of the vertical communication variable is $2.668>\mathrm{t}$ table, which is 2,000 . Ho is rejected, so it can be stated partially that vertical communication has a significant effect on organizational commitment. Lecturers communication in the university is built if people have a positive attitude towards themselves, positive feelings for communication situations are generally very important for effective interactions, similarities where Such communication will increase the commitment of the lecturer organization in Serambi Mekah University

Organizational commitment is an important behavioral dimension that can be used to assess employee tendencies, identify and engage someone who is relatively strong towards the organization. Moreover, to know the desire of organizational member, to maintain their membership in the organization is willing to strive for achieving organizational goals and accepting norms in the company. Organizational commitment defines feeling of trust in organizational values, willingness to try as well as possible for the benefit of the organization and loyalty and the desire to remain a member of the organization declared by an employee to his organization.

Simultaneous contribution of variable organizational culture, transformational leadership, and vertical communication to organizational commitment can be done by proving through a comparison of the value of $\mathrm{F}$ count with Ftable. By obtaining the value of Fcount $=81.403$, and Ftable $=2.77$. Because Fcount $>$ Ftable means that $\mathrm{Ho}$ is rejected and Ha is accepted, so it can be concluded that there is a simultaneous significant effect between $\mathrm{X} 1, \mathrm{X} 2$, and $\mathrm{X} 3$ on $\mathrm{Y}$. Someone who gets organizational commitment from lecturers usually has a record of attendance and usually performs better than in people who do not get organizational commitment.

\section{CONCLUSIONS}

Based on the results of the analysis and discussion in this study, several conclusions are presented as follows: organizational culture, transformational leadership, vertical communication, influence the lecturers' organizational commitment at Serambi Mekah University, Banda Aceh. Organizational culture has a positive direct effect on the organizational commitment of the lecturers. Transformational leadership has a positive direct effect on the Lecturers' organizational commitment in Serambi Mekah University. Vertical communication has a positive direct effect on the commitment of lecturers. In other words, the better the organizational culture is, the higher the lecturers' organizational commitment. The better the transformational leadership is, the higher the lecturers' organizational commitment. And the better the vertical communication is, the higher the lecturer' organizational commitment in Serambi Mekah University, Banda Aceh.

\section{REFERENCES}

Antonakis, Avoliodan, Sivasubramaniam. 2003. Context and leadership: An examination of the then-factor fullrange leadership theory using the Multifactor Leadership Questionnaire. The Leadership Quarterly.

Colquitt, Jason. A, Jeffery ALapine \& Michel J Wasson.2009, Organizational Bahavior Improving Performance and Commitment in the Workplace. New York: McGraw Hill Companies.

Eugene F. Mc. Kenna., Alan, Glendon. 1995. Human Safety and Risk Management. New York: Champman \& Hall.

Gibson, James L. Jhon M Ivancevich and James H. Donnelly, Jr. 2000. Organizational Boston: McGraw-Hill Companise.

Haryani. Sri. 2001. Business Communication. UPP AMP YKPN: YogyakartaKreitner, Robert and Kinicki. 2007. Organizational Behavior. 8th Edition. Boston: McGraw-Hill.

Khuntia, R., and Suar, D. 2004. A Scale to Assess Ethical Leadership of Indian Private and Public Sector Managers, Journal of Business Ethics, Vol. 49, No. 1, pp. 13-26.

Kreitner, Robert and Kinicki. 2005. Organizational Behavior. Jakarta.Salemba four.

Luthans, Fred, 2006. Organizational Behavior. Ten Edition. Translator: Vivin Andika et al. McGraw-Hill Companies Inc.

Mathis Robert L. and Jackson John H. 2006, Human Resource Management, Language Transfer. Salemba Empat. Jakarta.

Muhammad, Arni, 2007. Organizational Communication. Jakarta: Bumi Aksara,

Newstrom and Davis, Keith, 2000, Behavior in Organizations. Jakarta: Erlangga.

Robbins, Stephen P and Timothy A Judge. 2007. Organizational Behavior. Jakarta: Salemba Empat.

Robbins, Stephen P. \& Timothy A. Judge. 2009. Organizational Behavior. Pearson International Edition, PrenticeHall: USA 
Robert A. Baron, and Jerald Greenberg. 2000. Behavior in Organization. New Jersey: Prentice Hall. Sopiah. 2008. Organizational Behavior. Yogyakarta: Andi Offset.

Sutrisno, Edy, 2009, Human Resource Management. Jakarta: Kencana.

Uno. Hamzah B. 2008. The Motivation \& Measurement Theory. Analysis in Education. Jakarta: Bumi Aksara. Yukl, Gary, 2010, Leadership in Organizations, Fifth Edition. Jakarta: PT. Index. 